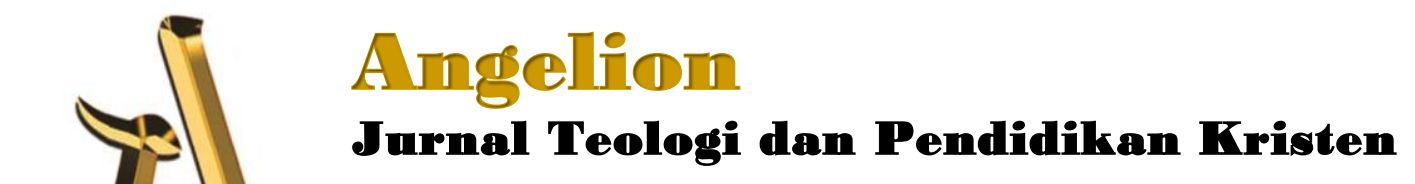

Vol 2, No 1, Juni 2021; 18-35

e-ISSN : 2723-3324

Available at: e-journal.sttberitahidup.ac.id/index.php/jan/index

\title{
Keselamatan Oleh Iman Berdasarkan Surat Roma
}

\author{
William Hermon Beltsazar Dongoran ${ }^{1}$ \\ pdt.williamhermon@gmail.com
}

\begin{abstract}
Salvation by faith is a theological topic that is still being discussed and debated among theologians. The classical debate between Calvinism and Arminianism is still developing from both the point of view of dogmatics and systematic theology. Because the differences that exist make the understanding of salvation also different. In the discussion about salvation often the discussion does not go well, because each stick to the concept of salvation based on dogma. In understanding the systematic theology related to salvation is also influenced by dogma and ignores elements of biblical theology, the concept of salvation by faith written by Paul needs to be reexamined, considering that Paul's Theology is very sharp in reviewing the Theology of Salvation by Faith in Romans. It is very interesting that the line of thought in Romans which can be examined especially regarding salvation by faith. So seeking the truth about salvation by faith in Rome is not a regression in theology. In fact, examining Romans is a very basic step in seeking the truth about salvation by faith. The problem in this research is to find an understanding of salvation by faith based on Romans and what dimensions are in Romans that become the flow of thinking in discussing salvation by faith. The conclusion of this research. The author finds that Paul is very consistent in making God's righteousness the main concept in understanding salvation by faith. And consistency makes God's righteousness the center of the development of salvation by faith into something that is always new.
\end{abstract}

Keywords: Safety; Faith; God's righteousness; Romans; Dimensions of Theology.

\section{Abstrak}

Keselamatan oleh iman adalah merupakan topik teologi yang masih terus dibicarakan dan diperdebatkan di kalangan para teolog. Perdebatan klasik antara Calvinisme dan Arminianisme masih terus berkembang baik dari sudut dogmatika dan juga Teologi Sistematika. Karena perbedaan yang ada membuat pemahaman tentang keselamatan juga berbeda. Dalam diskusi tentang keselamatan sering kali diskusi menjadi tidak berjalan dengan baik, karena masing-masing bertahan dengan konsep keselamatan yang berdasarkan dogma. Dalam memahami Teologi Sistematika yang berkaitan dengan keselamatan juga dipengaruhi oleh dogma dan mengabaikan unsur Teologi biblika, Konsep Keselamatan Oleh Iman yang ditulis oleh Paulus perlu dikaji kembali, mengingat Teologi Paulus sangat tajam sekali dalam mengulas Teologi Keselamatan Oleh Iman dalam Surat Roma. Sangat menarik sekali alur berpikir dalam Surat Roma yang dapat diteliti khususnya mengenai keselamatan oleh iman. Sehingga mencari kebenaran tentang keselamatan oleh iman dalam Roma bukanlah sebuah kemunduran di dalam berteologi. Justru meneliti surat Roma adalah

\footnotetext{
${ }^{1}$ Sekolah Tinggi Teologi Doulos Jakarta
} 
langkah yang sangat mendasar dalam mencari kebenaran tentang keselamatan oleh iman. Masalah dalam penelitian ini adalah untuk mencari pengertian mengenai keselamatan oleh iman berdasarkan Surat Roma dan dimensi apa saja yang ada dalam surat Roma yang menjadi alur berpikir dalam membahas keselamatan oleh iman. Kesimpulan dari penelitian ini Penulis menemukan bahwa Paulus sangat konsisten untuk menjadikan kebenaran Allah menjadi konsep utama dalam memahami keselamatan oleh iman. Dan konsistensi menjadikan kebenaran Alllah menjadi pusat dari pengembangan keselamatan oleh iman menjadi sesuatu yang selalu baru.

Kata-kata kunci: Keselamatan; Iman; Kebenaran Allah; Surat Roma; Dimensi Teologi.

\section{PENDAHULUAN}

Keselamatan adalah pokok pengajaran penting dalam Alkitab. Semua rencana Allah untuk manusia dinyatakan melalui keselamatan yang telah Dia rencanakan dari sejak awal. Meskipun pengajaran keselamatan penting, tetapi pokok ini sering sekali menjadi pokok yang diperdebatkan. Perdebatan yang sering terjadi di kalangan orang percaya menjadi isu penting di tengah perkembangan zaman yang ada.

Isu perdebatan yang muncul mengenai keselamatan dalam pengamatan Penulis yang paling klasik adalah berkaitan dengan dogma pemahaman Calvinisme dan Arminianisme. "Dua-duanya berpegang pada doktrin Sola Gratia, yaitu bahwa manusia diselamatkan oleh Anugerah. Arminian memilih lepas total dari campur tangan Tuhan. ${ }^{2}$ Sedangkan Calvinis juga meyakini ada kemungkinan untuk memilih tetapi pilihan itu tidak lepas dari campur tangan Tuhan."3 Calvinisme dikembangkan pada awalnya oleh Yohanes Calvin dengan konsep keselamatan yang terkenal dengan "tulip" yang berkembang dalam dunia teologi dengan konsep 5 pokok Calvinisme. Dalam pokok-pokok keselamatannya Calvin lebih memfokuskan keselamatan sepenuhnya Allah yang mengerjakannya, manusia tidak ada andil di dalamnya. Sedangkan Arminianisme dikembangkan oleh Yakobus Arminius. Dalam konsep keselamatannya Arminian menentang apa yang diyakini oleh Calvin. Arminian lebih menekankan kebebasan mutlak. Keselamatan yang ditawarkan Allah bagi Arminian harus direspons oleh manusia, sedangkan bagi Calvin karena Allah sudah menetapkan dari sejak kekekalan siapa yang akan diselamatkannya. Di samping itu juga ada perdebatan memahami keselamatan dari sisi Teologi Sistematika yaitu perdebatan masalah memahami ordo salutis. Perdebatan ini juga berkembang di kalangan Calvinisme, Arminianisme, Katolik, Lutheran.

\footnotetext{
${ }^{2}$ Dick Mak, Berteologi Abad XX-Keselamatan, (Jakarta: Literatur Perkantas, 2015), 636.

${ }^{3}$ Ibid.
} 
Ordo Salutis adalah: "tindakan yang mencoba menyusun proses karya keselamatan yang telah dikerjakan di dalam Kristus, direalisasikan secara subjektif di dalam hati dan kehidupan orang-orang berdosa."4 Adapun tujuannya adalah: "untuk mendeskripsikan urutan logis dan juga interelasi dari berbagai gerakan Roh Kudus dalam menerapkan karya penebusan itu." 5 Konsep pemahaman mengenai ordo salutis ini berbeda-beda. Misalnya pandangan Reformed: "Di mulai dengan asumsi bahwa keadaan spiritual manusia bergantung kepada keadaannya, yaitu dalam hubungannya dengan hukum dan hanya oleh kebenaran yang diberikan Tuhan Yesus orang berdosa dapat dilepaskan dari pengaruh dosa." Dikembangkan oleh Bavinck sebagaimana dikutip oleh Berkof dengan menyebutkan bahwa berkat keselamatan: "Memperbaiki hubungan dengan Yesus melalui pembenaran, memperbaharui manusia melalui kelahiran kembali, panggilan dalam hati, pertobatan, pembaharuan dan penyucian. Menyediakan warisan kekal bagi manusia."7 Sementara Lutheran lebih menekankan: "di dalam Kristus, Allah diperdamaikan dengan dunia manusia. Allah mengumumkan kenyataan ini melalui Injil dan menawarkan agar manusia memilikinya secara subyektif dari pengampunan dosa atau pembenaran." ${ }^{\text {K }}$ Katolik lebih menekankan: "Kelahiran kembali melalui baptisan, sekalipun manusia dapat menerima atau menolak anugerah itu, kalau manusia menerimanya akan berubah menjadi gratia cooperans." $"$ Bila diurutkan akan susunannya menjadi tujuh bagian penting: "penerimaan Firman Tuhan, menyadari keadaan diri berdosa, berharap pada kasih karunia Allah, mencintai Tuhan, meninggalkan dosa, kesediaan untuk menaati perintah Allah dan dibaptiskan." 10 Pandangan Arninian: "mereka meyakini bahwa keselamatan adalah karya Allah. Allah membuka kesempatan untuk semua manusia, tetapi tergantung manusia apakah meresponsnya. Kematian Kristus persembahan dan pemuasan bagi dosa dunia."11

Perlu disadari bahwa pemahaman perbedaan yang ada sudah tentu muncul dari konsep menafsirkan Alkitab secara biblikal. Tidak bisa dipungkiri bahwa perbedaan penafsiran pastilah akan membuat doktrin berbeda dan pemahaman terhadap teologi pun akan berbeda. Meskipun perbedaan ada, Peneliti merasa perlu menyuguhkan konsep Keselamatan Oleh Iman Berdasarkan Surat Roma. Dalam pengamatan Penulis secara teologi

\footnotetext{
${ }^{4}$ Anthony A Hoekma, Diselamatkan Oleh Anugerah, (Surabaya, Momentum, 2006), 11.

${ }^{5}$ Ibid.

${ }^{6}$ Louis Berkof, Teologi Sistimatika Doktrin Keselamatan, (Jakarta: Lembaga Reformed Injili Indonesia, 1997), 11.

${ }^{7}$ Ibid, 13.

${ }^{8}$ Ibid, 16.

${ }^{9}$ Ibid, 17.

${ }^{10}$ Ibid, 17.

${ }^{11}$ Louis Berkof,19.
} 
biblikal dalam surat Roma sangat kaya dengan doktrin Keselamatan oleh iman. Paulus sangat terstruktur dalam menyorotinya. Sama seperti apa yang dikatakan oleh David K. Lowery: "Surat yang mendekati Teologi Sistematika adalah Surat Roma, fokusnya bukan pada Teologi secara umum tetapi suatu tulisan tentang berita keselamatan." ${ }^{12}$ Konsep Teologi Alkitab Paulus memang dipaparkan secara rapi. Penulis merasa perlu mengangkat topik ini untuk menjawab fenomena yang muncul dari perdebatan yang belum selesai sampai saat ini.

Sehingga Rumusan Masalah untuk penelitian ini adalah: apakah yang di maksud dengan keselamatan oleh iman berdasarkan surat Roma? Dan dimensi apa saja yang dikembangkan dalam surat Roma untuk memahami keselamatan oleh iman? Tujuan dari penelitian ini adalah untuk memaparkan konsep keselamatan oleh iman berdasarkan surat Roma. Hasil dari penelitian ini akan memperkaya pemahaman ilmu Teologi khususnya Soteriologi secara biblikal.

\section{METODE}

Peneliti menggunakan penelitian Teologi Biblikal kualitatif. Sebagaimana yang dikatakan oleh Stevri Lumintang: "penelitian teologi biblikal adalah penelitian untuk menemukan arti teks Alkitab untuk pembaca pertama (meant) dan arti teks itu faktual untuk pembaca masa kini (mean or means)." 13

Dalam menggunakan metode ini Peneliti akan mengamati teks kitab Roma dengan menggunakan pengamatan hermeneutika biblikal. Metode pengamatan biblika menggunakan metode kontekstual, literal, gramatikal. Metode ini akan mengemas pemahaman teologi biblikal sesuai dengan pola pikir dari Penulis Surat dalam hal ini Paulus sebagai Penulis Surat Roma (Rm 1:1).

Di samping itu juga Peneliti akan menggunakan buku-buku pustaka dari para pakar yang sudah meneliti surat ini. Penulis yang pernah meneliti tentang teologi dalam Surat Roma adalah “Aya Susanti” ${ }^{14}$ Sorotannya dalam jurnal beliau menyoroti Keselamatan dalam Konsep Rasul Paulus. Dalam tulisannya beliau menyoroti pandangan umum Paulus tentang

\footnotetext{
${ }^{12}$ Roy B.Zuck, Editor, A Biblical Theology Of The New Testament, (Malang: Penerbit Gandum Mas, 2011), 279.

${ }^{13}$ Stevri Lumintang \& Danik Astuti Lumintang, Theologi Penelitian dan Penelitian Theologis, (Jakarta: Geneva Insani Indonesia, 2016), 124.

${ }^{14}$ Aya Susanti menulis dalam Jurnal Teologi Integritas. Beliau adalah dosen di Sekolah Tinggi Teologi Jaffray Jakarta.
} 
keselamatan dan pandangan keselamatan secara khusus dalam surat Roma. Memang ada perbedaan sorotan dari apa sudah ditulis beliau dengan apa yang akan Penulis paparkan.

Dalam menggunakan Penelitian Teologi Biblikal Kualitatif, Penulis akan lebih banyak memperhatikan alur berpikir Paulus dalam mengemukakan keselamatan oleh iman. Sudah tentu Peneliti akan memulai dari mengamati pola berpikirnya yang dimulai dari ayat kunci dalam Rm 1:16-17. Setelah ayat ini dikemukakan Paulus langsung membicarakan dimensi demi dimensi yang menyebabkan keselamatan oleh iman itu diperlukan. Peneliti akan menganalisis pemahaman Paulus secara teliti.

\section{HASIL DAN PEMBAHASAN}

Kitab Roma adalah kitab yang ditulis oleh Rasul Paulus. Hal ini dinyatakan melalui

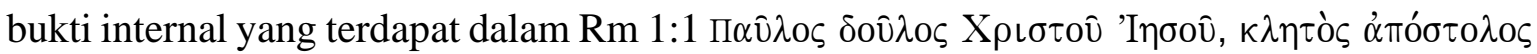

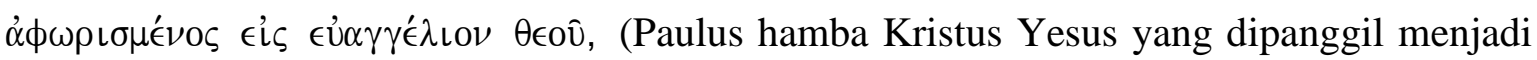

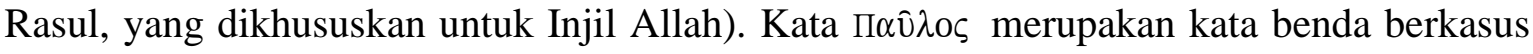
Nominatif. "Penggunaan kasus nominatif sebagai kasus penamaan, yang berperan sebagai subjek dari verba finit. Verba tersebut entah dinyatakan secara eksplisit, bisa juga dipahami

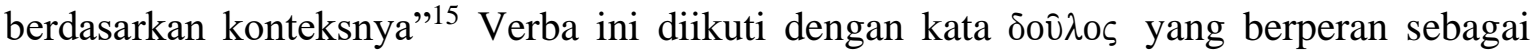
"nominatif aposisi. di mana nomina tersebut beraposisi dengan nominatif lain"16 Dalam

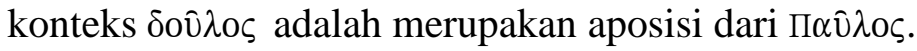

Jadi Paulus sebagai Penulis surat ini memperkenalkan dirinya sebagai hamba Kristus Yesus, dipanggil menjadi Rasul dikhususkan untuk Injil. Dan hal-hal yang berkenaan dengan Injil dijelaskan dalam ayat 2-7. Injil "telah dijanjikan-Nya sebelumnya dengan perantaraan nabi-nabi-Nya dalam kitab-kitab suci" (ayat 2) menjelaskan bahwa Injil. Ini adalah bentuk Indikatif Aorist Middle (deponen). "Injil bukanlah suatu pemikiran susulan dari Allah, melainkan suatu rencana abadi yang memang dimaksudkan oleh Allah. (lih Kej 3:15; Yes 53; Mzm 118; Mrk 10:45; Luk 2:22; Kis 2:23; 3:18; 4:28; Tit 1:2)."17 Hal-hal ini juga merujuk kepada: "khotbah-khotbah awal di kitab Kisah para Rasul (kerigma) penyataan bahwa Yesus adalah penggenapan dari nubuatan dan janji-janji dalam Perjanjian Lama." 18 Injil juga membicarakan Rm 1:3 "tentang Anak-Nya" "diperanakkan dari keturunan Daud" Ini menghubungkan nubuatan dari 2 Samuel 7. Mesias adalah keturunan raja Daud. Dalam

\footnotetext{
${ }^{15}$ Petrus Maryono, Gramatika dan Sintaksis Perjanjian Baru, (Yogyakarta:STTII, 2016), 22.

${ }^{16}$ Ibid, 25.

${ }^{17}$ Bob Utley, Kumpulan Komentari Panduan Belajar Perjanjian Baru, Vol. 5, (Texas: Bible Lessons International, Marshall, 2010), 11.

${ }^{18}$ Ibid.
} 
Rm 1:4 Injil juga membicarakan tentang: "kebangkitan-Nya dari antara orang mati, bahwa Ia adalah Anak Allah yang berkuasa, Yesus Kristus Tuhan kita.” Untuk panggilan Injil inilah Paulus rindu untuk datang ke Roma, tujuannya dinyatakan dalam Rm 1:9-15. Untuk memberitahu mereka bahwa Paulus ingin datang bertemu dengan mereka. Demikian akan menambah dukungan dari gereja di Roma sebagai pendukung misinya ke Spanyol. Untuk memberikan pengajaran yang jelas dan lengkap tentang keselamatan karena iman. Untuk memulihkan hubungan Yahudi non-Yahudi dalam persekutuan orang Kristen di Roma. Untuk menjelaskan tentang kebenaran Allah.

Apa yang Paulus hendak bicarakan dinyatakan melalui tulisan yang panjang yang terstruktur dengan rapi mulai dari Rm 1:16-17-16. Semua pembicaraannya dikemas dengan konsep pemahaman yang jelas tentang keselamatan oleh iman dan dimensi dari konsep keselamatan oleh iman.

\section{Pengertian Keselamatan Oleh Iman Berdasarkan surat Roma}

Kata keselamatan dalam bahasa Yunani berasal dari kata: "soteria dan sozo yang artinya menyelamatkan. Bagi Paulus istilah itu memiliki arti kegiatan Allah yang menyelamatkan dalam arti yang lebih luas menyangkut pembebasan ilahi dari dosa, daging dan hukum Taurat." ${ }^{19}$ Untuk memahami pengertian keselamatan oleh iman berdasarkan surat Roma perlu memperhatikan Rm 1:16-17 sebagai ayat tema untuk memahami pola pikir

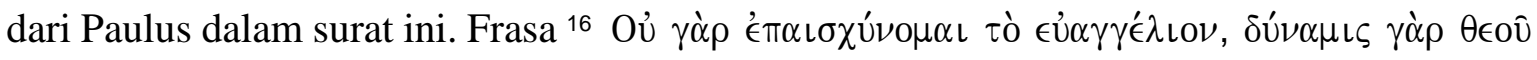

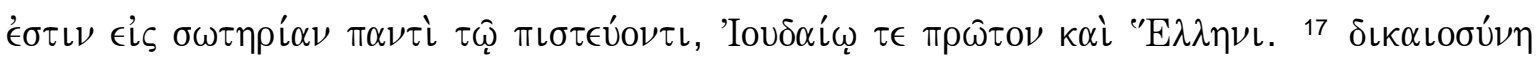

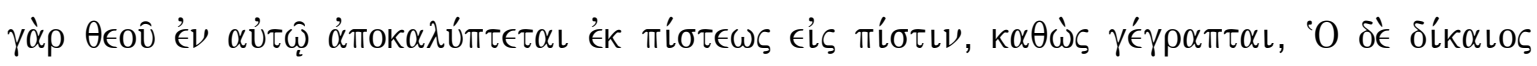

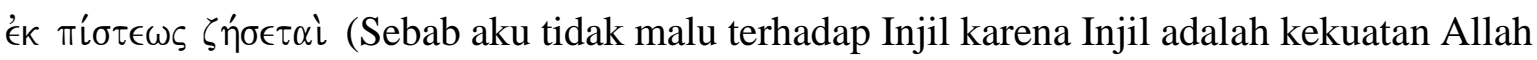
untuk keselamatan bagi setiap orang yang percaya pertama-tama bagi orang Yahudi dan juga bagi orang yang bukan Yahudi sebab kebenaran Allah dinyatakan di dalamnya dari iman kepada iman sebab ada tertulis orang benara akan hidup oleh iman).

Bila memperhatikan teks ini ada dua hal yang dijelaskan: yang pertama bahwa Injil adalah kekuatan Allah yang di dalamnya ada keselamatan bagi orang yang percaya baik Yahudi maupun Yunani. Yang kedua di dalam Injil dinyatakan kebenaran Allah yang di mulai dari iman dan memimpin kepada iman, dan orang benar akan hidup oleh iman.

Beberapa kata penting yang perlu diperhatikan untuk frasa kalimat: "Sebab aku tidak malu terhadap Injil karena Injil adalah kekuatan Allah untuk keselamatan bagi setiap orang yang percaya pertama-tama bagi orang Yahudi dan juga bagi orang yang bukan Yahudi

${ }^{19}$ C.Marvin Pate, Teologi Paulus (Malang: Penerbit Gandum Mas, 2004), 112. 
.. ”adalah kata Injil yang berasal dari kata gospel dalam bahasa Inggris dan euangelion dalam bahasa Yunani. Kata ini miliki pengertian: "kabar baik tentang kerajaan Allah dan keselamatan dari Tuhan Yesus melalui penebusan di dalam kematian, kebangkitan dan

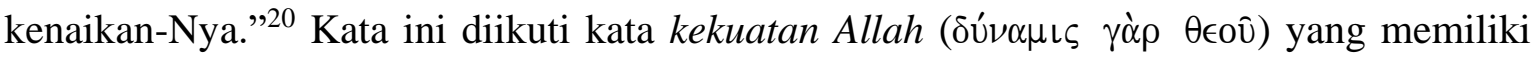
pengertian: "menunjukkan kekuatan yang sangat berkuasa yang berlawanan dengan kekuatan supranatural; sebagai kapasitas untuk sesuatu kemampuan, kapabilitas."21 Sedangkan kata keselamatan berasal dari kata $\sigma \omega \tau \eta \rho i ́ \alpha \nu$ dari akar kata swthria yang adalah merupakan kata benda berkasus akusatif yang merupakan objek langsung dari "kekuatan Allah" yang dijelaskan dengan menggunakan verba estin yang berasal dari verba eimi yang menjelaskan kekuatan yang tidak berubah. Kekuatan yang punya kualitas yang tidak dapat dibatasi oleh kuasa apa pun. Rupanya Paulus menyebutkan Injil itu sebagai kekuatan yang melebih segalanya. Jadi Injil itu adalah kekuatan Allah yang jangkauannya adalah keselamatan yang mampu menyelamatkan baik orang Yahudi maupun orang Yunani, namun jangkauan keselamatan itu hanya bagi orang yang berdosa yang mau percaya kepada Injil.

Frasa yang kedua yang harus diperhatikan adalah frasa: "sebab kebenaran Allah dinyatakan di dalamnya dari iman kepada iman sebab ada tertulis orang benara akan hidup

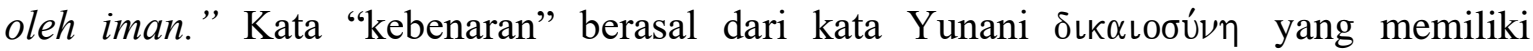
pengertian, "karakter atau kualitas dari menjadi benar atau adil dan ini hanyalah merupakan atribut Allah." ${ }^{22}$ Kebenaran ini dinyatakan di dalam Injil, sehingga mampu menyelamatkan orang berdosa yang percaya kepada Injil yang di dalamnya ada kebenaran Allah. Kata Iman atau percaya berasal dari kata $\pi\llcorner\sigma \tau \iota \varsigma$ yang penggunaannya menunjuk kepada: trust: trust worthiness." 23 Jadi iman itu adalah: "kepercayaan yang dapat dipercaya karena didasarkan pada suatu pengetahuan yang dinyatakan oleh Allah yang telah memindahkan dari gelap kepada terang." 24

Jadi dari uraian di atas pengertian keselamatan oleh iman berdasarkan surat Roma adalah: Kebenaran Allah yang dinyatakan melalui kekuatan Allah di dalam Injil kepada orang berdosa yang percaya.

\footnotetext{
${ }^{20}$ W.E Vine, Merril F Unger, William White Jr, Vine Complete Expository Dictionary Of Old And New Testament Words (London: Thomas Nelson Publishers, tt), 275.

${ }^{21}$ Bibleworks, Friberg Lexicon.

22 W.E Vine, Merril F Unger, William White Jr, 535.

${ }^{23}$ Ibid, 222.

${ }^{24}$ RC, Sproul, Kebenaran-Kebenaran Dasar Iman Kristen, (Malang: Seminari Alkitab Asia Tenggara, 2016), 245.
} 


\section{Dimensi Keselamatan Oleh Iman Berdasarkan Surat Roma}

Yang dimaksud dengan Dimensi Keselamatan oleh iman menurut surat Roma adalah Kebenaran Allah yang dinyatakan kepada orang berdosa melalui pengorbanan Tuhan Yesus, Sehingga dosa tidak lagi berkuasa atas hidupnya, karena sekarang statusnya sebagai orang yang dibenarkan, dikuduskan dan karena imannya memulai perjalanan hidup rohani dengan Tuhan.

Kebenaran Allah yang dimaksudkan dalam bagian ini adalah bukan sekadar "atribut Allah atau aktivitas Allah, bukan sekadar menyatakan diri sebagai Dia yang benar atau menyatakan diri dalam kebenaran-Nya yang menyelamatkan atau bukan sekadar apa yang manusia miliki agar dapat berdiri dalam penghakiman Ilahi." ${ }^{25}$ Tetapi yang di maksud dengan kebenaran Allah dalam bagian ini harus dipahami bukan sekadar dari pandangan ilahi tetapi harus di lihat dari sudut manusia yang akan mendapatkan kebenaran Ilahi itu. Sehingga kebenaran Allah dalam bagian ini lebih merujuk kepada: "kebenaran itu akan memampukan manusia untuk berdiri di hadapan Allah ( $\mathrm{Rm} 1: 17$; $\mathrm{Rm} 2: 13 ; 3: 20)$, dan bebas dari penghakiman-Nya. Kebenaran ini Allah kenakan kepada manusia dan berlawanan dengan kebenaran manusia itu sendiri." 26 Dalam penjelasan ini kebenaran Allah masuk dalam "kategori forensik dan memiliki arti eskatologis: kebenaran adalah apa yang dituntut dari manusia agar bisa bebas dari penghakiman Ilahi." ${ }^{27}$ Dari penjelasan ini dapat disimpulkan bahwa kebenaran Allah adalah sesuatu yang Allah berikan kepada manusia yang berdosa untuk mampu berdiri dan dinyatakan benar dan bebas dari penghakiman Ilahi.

Kebenaran Allah tersebut dinyatakan kepada manusia yang berdosa melalui keselamatan oleh iman yang Peneliti dapat lihat dari empat dimensi.

\section{Penyelesaian Dosa}

Alur berpikir mengenai penyelesaian dosa dijelaskan dalam $\mathrm{Rm}$ 1-3.Dimulai dengan Rm 1:18-3:31, setelah Paulus menjelaskan tentang kebenaran Allah yang dinyatakan kepada manusia yang berdosa melalui penebusan Tuhan Yesus. Rm 1:18 di mulai dengan kata "sebab (gar) yang menjelaskan mengapa kebenaran Allah dibutuhkan oleh manusia yang berdosa itu. Penyebab kebenaran Allah dibutuhkan dijelaskan dalam Rm 1:18 dengan kata:

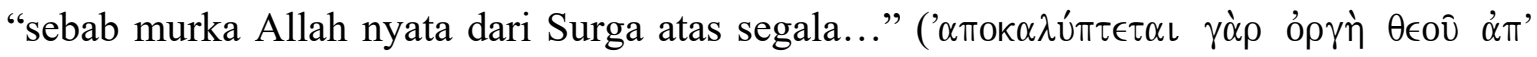

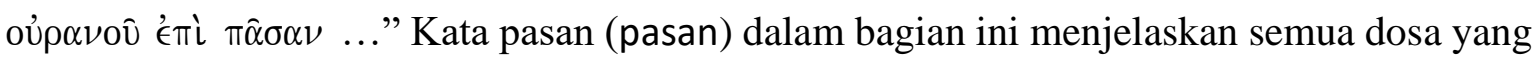

\footnotetext{
${ }^{25}$ Herman Ridderbos, Paulus Pemikiran Utama Teologinya,(Surabaya: Momentum, 2018), 165.

${ }^{26}$ Ibid.

27 Ibid.
} 
dilakukan manusia sehingga Allah menjadi murka. Kata "murka" (ojrhh) dalam bagian ini memiliki beberapa pengertian: "wrath, anger; retribution, punishment; revenge..." ${ }^{28}$ Murka yang menyebabkan dijatuhinya hukuman. Murka Allah itu dijelaskan dalam Rm 1:18-20. Murka Allah nyata: diungkapkan- to reveal -' $\alpha \pi 0 \kappa \alpha \lambda u ́ \pi \tau \epsilon \tau \iota \iota$ dari surga (18a), "Perhatikan bahwa murka itu dinyatakan bukan sesuatu yang dapat diamati manusia, dan bahwa murka itu ditujukan kepada semua bentuk kejahatan." ${ }^{29}$ Kata surga di sini merujuk kepada takhta Allah sebagai pengadil bagi manusia yang berdosa. Allah murka dari takhta-Nya atas dosa yang dilakukan oleh manusia. Penyebab adalah karena kefasikan dan kelaliman manusia, yang menindas kebenaran dengan kelaliman. (18b-20a). Akibatnya “...mereka tidak dapat berdalih (20b). Mengapa Allah murka? Rupanya murka Allah ini disebabkan: "mengabaikan Allah (21-23); kecemaran (24); penyembahan berhala (25); hubungan homo (26-27); kebejatan (28). Atas semua dosa ini "Allah menyerahkan mereka kepada keinginan hati mereka akan kecemaran (24). Allah menyerahkan mereka kepada hawa nafsu yang memalukan (26) dan akhirnya Allah menyerahkan mereka kepada pikiran-pikiran yang terkutuk, sehingga mereka melakukan apa yang tidak pantas. Itulah murka Allah atas dosa semua orang yang belum percaya. Dalam Rm 2 dijelaskan tentang dosa bangsa Yahudi. Dosa ini berkembang karena suka menghakimi orang lain (2:1-5). Kecenderungan orang-orang Yahudi suka membenarkan diri sendiri. Hal ini disebabkan karena: "mereka menganggap memahami hukum Taurat, tetapi mereka lebih mengikuti diri sendiri daripada melakukan hukum Taurat." 30 Sehingga Tuhan akan membalas: "tiap-tiap orang menurut perbuatannya (2:6-10); Tuhan menghukum tanpa membedakan (Rm 2:11-16); sekalipun bangsa Yahudi mempunyai kebanggaan sebagai orang Yahudi." 31 Dalam Rm 3 dijelaskan tentang dosa semua orang. Semua orang tetap bersalah sehingga memerlukan pembenaran oleh iman melalui kebenaran Allah (Rm 3:9-20).

Dalam dimensi ini dinyatakan bahwa manusia tidak mampu membenarkan diri-Nya di hadapan Allah. Hal ini terjadi karena manusia terikat dengan dosa warisan yang di warisinya dari Adam sampai kepada orang tuanya. Dan juga dosa pribadi yang dilakukannya karena pemberontakannya kepada Allah.

\footnotetext{
${ }^{28}$ UBS Lexicon, Bibleworks 7.

${ }^{29}$ Leon Morris, Teologi Perjanjian Baru (Malang: Penerbit Gandum Mas,2014), 83.

${ }^{30}$ R.A Jaffray, Tafsiran Roma, (Bandung: Kalam Hidup, 2007), 41.

${ }^{31}$ Ibid, 40-43.
} 


\section{Melalui kebenaran Allah}

Yang dimaksud dengan kebenaran Allah di dalam bagian ini adalah: kekudusan atau kesempurnaan yang merupakan sifat Allah, tetapi diterapkan kepada orang berdosa di dalam Kristus. Ini berarti kebenaran Allah dinyatakan kepada manusia yang berdosa itu melalui pengorbanan Tuhan Yesus.

Hal ini menyatakan bahwa usaha demi usaha yang dilakukan oleh orang berdosa untuk menyelesaikan dosanya di hadapan Allah tidaklah terselesaikan tanpa kebenaran Allah. Dosa tidaklah memperoleh penyelesaian yang sesuai dengan kehendak Allah. Semua usaha yang dilakukan oleh manusia adalah sesuatu yang relatif yang menurut pandangannya adalah benar karena kecenderungan manusia yang membenarkan diri di hadapan Allah.

Semua usaha yang dilakukannya hanyalah membawa orang berdosa tersebut kepada penghukuman. Karena dosa haruslah dipertanggung jawabkan di hadapan Allah. Maut adalah penghukuman kekal yang disediakan Allah bagi orang berdosa karena orang berdosa terpisah dari Allah karena kematian rohani.

Salah satu cara untuk menyelesaikan dosa manusia itu adalah melalui kebenaran Allah sendiri. Kebenaran Allah melalui iman dalam Yesus Kristus bagi semua orang yang percaya.

\section{Melalui Penebusan Yesus Kristus}

Satu-satunya cara yang dilakukan oleh Allah adalah dengan cara Allah sendiri. Allah di dalam anugerah-Nya karena kasih-Nya mengutus Yesus bagi orang berdosa untuk mati bagi orang berdosa ketika manusia itu masih terikat di dalam dosa.

Penebusan ini berkaitan dengan cara membayar tebusan melalui darah Tuhan Yesus sehingga terjadi pendamaian antara orang berdosa dengan Allah. Melalui penebusan Tuhan Yesus pemuasan amarah kebenaran Allah melalui penumpahan darah supaya manusia yang berdosa itu diperdamaikan dengan Allah.

Itulah sebabnya penyelesaian dosa hanya karena anugerah Allah, sehebat apapun manusia ia tidak mampu membebaskan dirinya dari dosa. Satu-satunya solusi yang disiapkan Allah adalah orang percaya harus percaya kepada pengorbanan Tuhan Yesus. Dengan demikian segala jalan yang dianggap benar oleh orang berdosa sekarang melalui penebusan Tuhan Yesus dinyatakan tidak mampu menyelesaikan dosa dari orang berdosa. Hanya penebusan Kristus yang mampu menyelesaikan dosa manusia di hadapan Allah. 


\section{Pembenaran}

Dimensi pembenaran dibicarakan dalam alur berpikir Paulus dalam Rm 4-5 sekalipun sudah disinggung dalam Rm 3:27-31 bahwa orang Yahudi tidak dapat memegahkan dirinya dengan hukum Taurat karena orang berdosa hanya bisa dibenarkan karena iman.

Kata pembenaran dalam Perjanjian Lama biasanya diterjemahkan menjadi: "membenarkan (justify) yang adalah hitsdiq, bentuk hippil dari tsadaq. Dalam BDB diterjemahkan menjadikan benar atau berbalik kepada kebenaran. Menjadikan benar harus dipahami secara forensik yaitu menyatakan atau mendeklarasikan sebagai yang benar."32 Penekanan utama dari pembenaran adalah: "meliputi pengampunan dan pengangkatan semua dosa dan akhir keterpisahan dengan Allah (Rm 4:6-7, 5:9-11) dan juga menyangkut pelimpahan kebenaran atas pribadi yang percaya berhak atas semua berkat."33

Jadi yang dimaksud dengan pembenaran dalam bagian ini adalah: Aksi Allah yang menyatakan orang berdosa benar, dan memperbaiki hubungan orang berdosa dengan-Nya. Pembenaran ini disejajarkan dengan keadilan-Nya, di mana Dia menghakimi dosa di dalam satu individu atau di dalam satu Pengganti yang tidak berdosa yaitu Yesus Kristus.

Karena semua orang telah berbuat dosa dan kehilangan kemuliaan Allah dan nasib akhirnya adalah penghukuman dan kematian kekal. Tetapi di dalam anugerah-Nya melalui penebusan Tuhan Yesus, Allah menunjukkan kasih-Nya kepada manusia yang berdosa itu dengan membenarkannya melalui darah-Nya. Pembenaran itu dinyatakan kepada orang berdosa oleh kasih karunia melalui iman.

\section{Oleh Kasih Karunia}

Yang di maksud dengan kasih karunia dalam bagian ini adalah pemberian Allah secara cuma-cuma melalui kebenaran-Nya kepada orang berdosa sehingga orang berdosa dinyatakan benar oleh karena imannya kepada darah Tuhan Yesus.

Ini berarti pembenaran di dapatkan oleh orang berdosa oleh kasih karunia melalui penebusan dari Tuhan Yesus yang telah mati bagi orang berdosa. Orang berdosa yang percaya kepada-Nya diposisikan sebagai orang benar melalui kasih karunia-Nya.

Pengorbanan Kristus yang telah berkorban bagi orang berdosa telah memosisikan orang berdosa yang percaya kepada Kristus sebagai orang yang dibenarkan. Pembenaran ini menyangkut pembebasan dari hukuman kekal dan kematian kekal. Sehingga posisi orang

\footnotetext{
32 Anthony A Hoekma, 204.

${ }^{33}$ Paul Ens, The Moody Handbook Of Theology, (Malang: Literatur SAAT, 2003), 403.
} 
percaya bukanlah orang yang terhukum dan terikat dengan dosa. Orang percaya yang dibenarkan memperoleh anugerah keselamatan.

\section{Melalui Iman}

Yang di maksud dengan iman dalam bagian ini adalah: Sikap percaya atau bersandar pada tindakan penebusan Kristus di kayu salib sebagai korban yang tidak berdosa, demi menanggung penghukuman dari Allah bagi orang-orang berdosa. Itu sebabnya orang berdosa dibenarkan hanya karena percayanya kepada pengorbanan Tuhan Yesus.

Iman menjadi alat untuk mempercayai akan apa yang dikerjakan oleh Allah melalui pengorbanan Tuhan Yesus, sehingga orang berdosa dinyatakan benar. Tanpa iman tidak mungkin orang berdosa berkenan kepada Allah. Tetapi melalui iman percayanya ketika orang berdosa percaya kepada Tuhan Yesus Kristus dibenarkan oleh Allah.

Akhirnya dimensi in menegaskan bahwa keselamatan oleh iman dasarnya adalah anugerah Allah yang membenarkan orang berdosa. Dengan adanya anugerah Allah di dalamnya akan meniadakan semua usaha manusia untuk membenarkan diri di hadapan Allah. Anugerah pembenaran Allah hanya perlu direspons melalui iman kepada Kristus.

\section{Pengudusan}

Dimensi Pengudusan adalah dimensi yang hanya bisa dibangun melalui proses pengudusan Allah sendiri di dalam anugerah-Nya. Allah yang mengerjakan pengudusan itu di dalam hidup orang percaya yang percaya kepada-Nya. Hal ini dibicarakan dalam alur berpikir Paulus dalam Rm 6-8. Pengudusan dalam bagian ini memiliki pengertian: "memisahkan diri untuk Allah, memperhitungkan Kristus sebagai kekudusan orang percaya, dibersihkan dari kejahatan moral, serta menjadi serupa dengan gambaran Kristus." ${ }^{\text {"34 Di }}$ samping itu juga Pengudusan dapat diartikan: "sebagai memiliki kesamaan yang aktual dengan gambar Allah." "35 Jadi pengudusan adalah : Kebenaran Allah yang ditanamkan dalam pengudusan melalui pengenalan yang benar akan Kristus. Dalam proses pengudusan orang percaya dituntun oleh Roh Kudus untuk hidup serupa dengan Kristus.

Dengan demikian proses pengudusan ini akan terlihat secara nyata dalam hidup orang percaya melalui kebenaran yang ditanamkan oleh Roh Kudus melalui kebebasan dari dosa ( $\mathrm{Rm}$ 6), bebas dari Hukum Taurat ( $\mathrm{Rm} 7)$, berjalan di dalam kuasa Allah ( $\mathrm{Rm} 8)$

\footnotetext{
${ }^{34}$ Henry C. Thiessen, Teologi Sistematika, (Malang: Penerbit Gandum Mas, 1992), 442.

${ }^{35}$ Milard J. Erickson, Teologi Kristen (Malang: Penerbit Gandum Mas, 2004), 192.
} 


\section{Bebas dari dosa}

Pengudusan itu berkenaan dengan pembebasan dari hidup di dalam daging kepada hidup di dalam Roh. Standar pengudusan hidup di dalam Roh adalah orang percaya tidak lagi mengikuti keinginan daging yang bekerja di dalam hidupnya. Hal ini didasarkan kepada anugerah Alah yang telah membebaskan orang-orang berdosa yang telah dibenarkan bebas dari dosa. Orang berdosa yang tadinya sebelum percaya kepada Tuhan Yesus dikuasai oleh dosa sekarang berkuasa atas dosa itu.

Dalam pengudusan ini Allah memberikan sifat baru, hidup yang baru dan kebebasan yang baru. Dengan adanya sifat yang baru sekarang orang yang percaya berbagi dalam kehidupan baru-Nya, hidup lamanya sudah mati tetapi sekarang hidup bagi Allah. Dengan demikian orang yang dikuduskan tidak lagi berespons terhadap kuasa yang lama dan sekarang berjalan dengan hidup yang baru.

Orang yang dikuduskan juga berjalan dengan hidup yang baru. Hal yang sangat menonjol yang dapat dilihat adalah -Kuasa dosa telah dipatahkan. Rasa mencintai dosa telah dikubur. Dan dosa tidak lagi berkuasa atas hidupnya. Dengan hidup yang baru orang yang dikuduskan meyakini bahwa kuasa dosa telah dipatahkan.

Dan akhirnya dengan pengudusan, orang percaya yang dikuduskan berjalan dengan kebebasan yang baru. Kebebasan yang dinyatakan dengan dosa anganlah berkuasa lagi atas kamu. Memberi dirimu sepenuhnya kepada Allah. Menampilkan kehidupan sebagai orang yang telah bebas. Dan memilih untuk menjadikan Allah menjadi tuannya. Sehingga pengudusan itu membuat orang yang dikuduskan untuk berkomitmen untuk taat kepada Kristus di dalam kebebasan yg sempurna.

\section{Bebas dari Hukum Taurat}

Pengudusan itu juga berkenaan kepada bebas dari hukum Taurat kepada hukum Kristus yang ada di dalam hukum kasih. Pembebasan ini dinyatakan dengan tidak bergantungnya orang percaya kepada aturan yang ada di dalam hukum Taurat. Orang percaya sekarang melalui anugerah pengudusan Allah sepenuhnya dituntun oleh Allah untuk hidup dalam hukum kasih.

Kematian Kristus membebaskan orang yang dikuduskan dari "ikatan" dengan Hukum, karena sekarang disatukan dengan Kristus. Taurat sepuluh perintah memenuhi tujuannya dengan melarang 'keinginan' untuk berdosa (Rom. 7:7). 
Orang percaya telah mati terhadap hukum ini ketika bergabung dengan Kristus $(7: 4,6)$. Sebab sepuluh Hukum Taurat adalah satu kesatuan, maka orang yang dikuduskan juga telah mati terhadap sembilan perintah lainnya.

Pengudusan ini juga berkaitan dengan kepastian keselamatan di dalam Kristus oleh iman. Oleh imannya orang percaya dipastikan pada masa kini dan masa yang akan datang telah mendapatkan kepastian keselamatan. Dan kepastian keselamatan inilah yang mendudukkan orang percaya sebagai orang-orang yang dipilih dan yang berhak mewarisi semua janji-janji Allah di dalam surga.

\section{Berjalan dalam kuasa Roh Kudus}

Sebelum orang yang dikuduskan percaya kepada Yesus kecenderungannya berjalan dalam dosa. Tetapi sekarang setelah percaya kepada Tuhan Yesus diberi kuasa untuk dapat berjalan di dalam kuasa-Nya.

Hal ini disebabkan oleh karena kemenangan Kristus atas kubur juga adalah milik orang percaya sekarang. kuasa dalam pengudusan diperoleh melalui pelayanan Roh, yang dibuktikan dengan kemenangan atas dosa, diadopsi ke dalam keluarga Tuhan sebagai anak dan mendapatkan jaminan keselamatan yang kekal yang sekali untuk selamanya.

\section{Perjalanan Hidup Rohani}

Dimensi perjalanan hidup rohani orang percaya menjadi dimensi yang dapat dilihat secara terukur apakah orang percaya benar berjalan di dalam keselamatan oleh iman. Sorotannya sangat nyata untuk pembuktiannya melalui kehidupan rohani yang ditampilkan setiap harinya. Alur berpikirnya dinyatakan dalam Rm 12-16.

Di mulai dengan kata "Karena itu (oûv) yang menjelaskan kepada hal yang sudah dibicarakan sebelumnya yang berkaitan dengan kebenaran Allah yang sudah Allah nyatakan melalui penyelesaian dosa, pembenaran dan pengudusan. Sekarang kepada orang yang sudah mengalami kebenaran Allah di dalam iman haruslah memulai perjalanan hidup rohaninya bersama dengan Kristus.

Istilah perjalanan hidup rohani dalam istilah teologi digunakan dengan istilah spiritual life, hidup baru di dalam Kristus, atau ada juga yang menggunakan dengan istilah hidup setelah pertobatan. Apa pun istilah yang dipakai Penulis lebih senang menggunakan perjalanan hidup rohani. Mengapa harus perjalanan? Karena setelah lahir baru kehidupan rohani bersama Kristus harus mulai dijalani, Keselamatan oleh iman bukan sekadar membawa orang yang percaya untuk masuk surga, Tetapi juga membicarakan hidup yang sekarang, Sehingga keselamatan oleh iman tidak hanya sekadar bicara percaya masuk surga, 
tetapi juga bicara memulai perjalanan hidup rohani bersama dengan Kristus. Ada empat indikator yang menjelaskan perjalanan hidup rohani.

\section{Pembaharuan Pikiran}

Hal ini dibicarakan dalam Rm 12: 1-2. Kehidupan rohani itu berkenaan dengan pembaharuan budi yang berkaitan dengan pikiran, Tadinya sebelum percaya Tuhan Yesus pola pikirnya terikat dengan dunia oleh karena tubuhnya adalah miliki dosa. Sekarang setelah percaya kepada Tuhan Yesus pola pikir itu berubah, tidak lagi memikirkan hal-hal yang duniawi, oleh karena tubuhnya telah dipersembahkan kepada Tuhan satu kali untuk selamanya.

Dan juga tubuh orang percaya sekarang menjadi miliki Kristus. Istilah kata "mempersembahkan" adalah merupakan aorist invinitive. Kata ini menegaskan pengertian mengorbankan (Rm 12:1). Jadi pembaharuan pikiran terjadi karena orang percaya sudah mengorbankan tubuhnya sebagai korban yang hidup, yang kudus dan berkenan kepada Allah. Sehingga pola pikir yang tadinya sepenuhnya dikuasai dunia sekarang berubah dikuasai oleh Allah sehingga mampu membedakan mana yang menjadi kehendak Allah, apa yang baik, yang berkenan kepada Allah dan yang sempurna. ${ }^{36}$ Pembaharuan pikiran itu juga berkenaan dengan persembahan tubuh yang sepenuhnya menjadi milik Kristus dan seharusnya orang percaya juga dapat mulai berpikir seperti Kristus. Salah tindakan yang harus dilakukan setelah mengalami pembaharuan pikiran adalah dengan hidup bersama dengan orang percaya lainnya dengan menyelaraskan pikiran tersebut melalui hidup dan menggunakan karunia yang telah dipercayakan kepada masing-masing orang percaya (Rm $12: 3-8)$.

\section{Bersukacita Dalam Pengharapan}

Kehidupan rohani yang dapat diukur dengan sukacita karena pengharapan yang akan datang. Pengharapan yang ada di dalam Kristus yang menguatkan untuk dapat sabar dalam kesesakan yang dibuktikan dengan bertekun dalam doa.

Pengharapan yang tidak terikat dengan apa yang dilihat sekarang tetapi pengharapan yang sepenuhnya dalam pengendalian daripada Roh Kudus. Sukacita yang murni karena dorongan Roh Kudus yang dikerjakan di dalam roh dan tampilkan dari dalam.

${ }^{36}$ Asih Rachmani Endang Sumiwi, "Pembaharuan Pikiran Pengikut Kristus Menurut Roma 12:2," Jurnal Teologi Berita Hidup 1, no. 1 (2018): 46-55, www.e-journal.sttberitahidup.ac.id/index.php/jbh. 


\section{Hidup dalam kasih}

Kehidupan rohani yang dapat diukur dengan tampilan hidup di dalam kasih. Untuk hal ini orang percaya harus mengganti kasih terhadap diri sendiri dengan kasih kepada sesama. Kasih kepada sesama dinyatakan dengan tidak saling menghakimi dengan saling menuduh dan mencurigai satu dengan yang lainnya.

Tampilan yang murni dikerjakan karena kuasa Roh Kudus yang bekerja di dalam pribadi orang percaya.

\section{Ketaatan kepada Pemerintah}

Kehidupan rohani yang diwujudkan dengan ketaatan kepada Pemerintah. Ketaatan ini oleh karena pemerintah berasal dari Allah dan ditetapkan oleh Allah. Ketaatan ini karena pemerintah adalah hamba Allah untuk kebaikan orang yang diselamatkan. Ketaatan ini juga adalah karena pemerintah adalah hamba Allah untuk membalaskan murka Allah.

Hal-hal yang perlu ditampilkan sebagai bentuk ketaatan kepada pemerintah adalah tidak melawan pemerintah, melakukan yang baik kepada pemerintah dan membayar apa yang perlu dibayar kepada pemerintah.

\section{KESIMPULAN}

Dari pembahasan di atas dapat disimpulkan bahwa Keselamatan oleh iman adalah Kebenaran Allah yang dinyatakan melalui kekuatan Allah di dalam Injil kepada orang berdosa yang percaya. Allah melalui kebenaran-Nya menyatakan keselamatan itu kepada orang percaya melalui empat dimensi yaitu dimensi penyelesaian dosa, dimensi pembenaran, dimensi pengudusan, dan dimensi perjalanan hidup rohani. Dimensi penyelesaian dosa diselesaikan dengan kebenaran Allah, yang harus dipahami secara forensik yaitu Allah menyatakan orang berdosa itu benar. Dan juga dosa bisa diselesaikan karena penebusan Tuhan Yesus Kristus. Penebusan Kristus menjadi jaminan untuk orang yang berdosa. Dimensi pembenaran adalah aksi Allah yang menyatakan orang berdosa benar, dan memperbaiki hubungan orang berdosa dengan-Nya. Pembenaran ini disejajarkan dengan keadilan-Nya. Di mana Dia menghakimi dosa di dalam satu individu atau di dalam satu Pengganti yang tidak berdosa yaitu Yesus Kristus. Dimensi Pembenaran dinyatakan kepada manusia oleh kasih karunia dan melalui iman. Dalam dimensi pembenaran harus diingat ini murni Allah yang menyatakannya kepada manusia yang berdosa. Dimensi Pengudusan adalah dimensi yang hanya bisa dibangun melalui proses pengudusan Allah sendiri di dalam anugerah-Nya. Allah yang mengerjakan pengudusan itu di dalam hidup orang percaya yang 
percaya kepada-Nya. Sehingga dalam pengudusannya orang percaya akan bebas dari dosa artinya orang percaya tidak dikuasai oleh dosa tetapi berkuasa atas dosa. Bebas dari hukum Taurat, artinya orang percaya tidak menghambakan dirinya kepada Taurat tetapi menghambakan dirinya kepada Kristus. Berjalan dengan Roh Kudus artinya orang percaya yang dalam pengudusan akan hidup menuju keserupaan dengan Kristus. Sedangkan dimensi perjalanan rohani adalah titik awal di mana orang percaya memulai hidup rohaninya bersama dengan Kristus. Persembahan tubuhnya kepada Kristus menjadi titik awal untuk hidup dalam pembaharuan pikiran, bersukacita dalam pengharapan, hidup dalam kasih dan ketaatan kepada pemerintah. Di samping itu juga Peneliti menemukan bahwa Keselamatan oleh iman berdasarkan surat Roma sepenuhnya dari Allah melalui kebenaran Allah yang dinyatakan kepada manusia yang berdosa.

\section{Kontribusi Penelitian}

Dalam mengembangkan metode Teologi Biblikal yang kualitatif memang seutuhnya harus memperhatikan gramatika dalam bahasa asli. Perlu konsisten untuk melihat teks dari bahasa Yunani. Namun di samping itu juga peneliti konsisten melihat alur berpikir teologi Paulus secara sistematika, sehingga penelitian ini hampir lebih banyak konsisten mengembangkan teks dalam surat Roma dan tidak membandingkan dengan kitab yang lain. Penulis lebih senang melihat pemikiran Paulus dalam surat ini.

\section{Rekomendasi Penelitian Lanjutan}

Penelitian yang Peneliti lakukan memang belum maksimal. Masih banyak hal yang bisa dikembangkan lebih dalam lagi. Misalnya dalam dimensi keselamatan oleh iman yang berkaitan dengan perjalanan hidup rohani masih banyak yang bisa diangkat menjadi topik penelitian selanjutnya. Misalnya: masalah pilihan Allah terhadap Israel dalam Rm 9-11 masalah karunia dalam Rm 12:3-7, masalah orang yang lemah imannya dalam Rm 14-15 dan tokoh-tokoh yang disebutkan oleh Paulus dalam Rm 16 bisa diteliti.

\section{Ucapan Terima kasih}

Peneliti berterima kasih kepada Sekolah Tinggi Teologi Berita Hidup, khususnya Program Studi Pasca Sarjana Doktoral yang mendorong para mahasiswa untuk menulis karya ilmiah melalui Jurnal Teologi dan menjadikan salah satu syarat untuk wisuda Program Doktoral. Terima kasih juga buat Ketua Pasca Sarjana yang memberikan ide untuk penelitian tulisan ini. 


\section{REFERENSI}

Berkof, Louis. Teologi Sistematika Doktrin Keselamatan. Jakarta: Lembaga Reformed Injili Indonesia, 1997.

Bibleworks. Friberg Lexicon.

Hoekma A, Anthony. Diselamatkan Oleh Anugerah. Surabaya: Momentum, 2006.

Jaffray, R.A. Tafsiran Roma. Bandung: Kalam Hidup, 2007.

Lumintang Stevri \& Lumintang, Danik Astuti. Theologi Penelitian dan Penelitian

Theologis. Jakarta: Geneva Insani Indonesia, 2016.

Mak, Dick. Berteologi Abad XX-Keselamatan. Jakarta: Literatur Perkantas, 2015.

Maryono,Petrus. Gramatika dan Sintaksis Perjanjian Baru. Yogyakarta: STTII, 2016.

Milard J. Erickson. Teologi Kristen. Malang: Penerbit Gandum Mas, 2004.

Morris, Leon. Teologi Perjanjian Baru. Malang: Penerbit Gandum Mas, 2014.

Pate, C. Marvin. Teologi Paulus. Malang: Penerbit Gandum Mas, 2004.

Paul Ens. The Moody Handbook Of Theology. Malang: Literatur SAAT, 2003.

Ridderbos, Herman. Paulus Pemikiran Utama Teologinya. Surabaya: Momentum, 2018.

Sproul, R.C. Kebenaran-Kebenaran Dasar Iman Kristen. Malang: Seminari Alkitab Asia Tenggara, 2016.

Susanti, Aya. Jurnal Teologi Integritas. Sekolah Tinggi Teologi Jaffray Jakarta.

Sumiwi, Asih Rachmani Endang. "Pembaharuan Pikiran Pengikut Kristus Menurut Roma 12:2." Jurnal Teologi Berita Hidup 1, no. 1 (2018): 46-55, www.ejournal.sttberitahidup.ac.id/index.php/jbh.

UBS Lexicon, Bibleworks 7.

Utley, Bob. Kumpulan Komentari Panduan Belajar Perjanjian Baru, Vol. 5. Texas: Bible Lessons International, Marshall, 2010.

Vine,W.E., Merril F. Unger, William White Jr. Vine Complete Expository Dictionary of Old And New Testament Words. London: Thomas Nelson Publishers.

Zuck, Roy B. (Editor). A Biblical Theology Of The New Testament. Malang: Penerbit Gandum Mas, 2011. 